\title{
Lembar Aktivitas Mahasiswa Materi Integral Jumlah Riemann Berdasarkan Teori Aksi, Proses, Objek, Skema (APOS)
}

\author{
Maya Saftari ${ }^{1 *}$, Sariman $^{2}$ \\ ${ }^{1}$ Teknik Informatika, ISB Atma Luhur Pangkalpinang, Indonesia \\ ${ }^{2}$ Sistem Informasi, ISB Atma Luhur Pangkalpinang, Indonesia \\ *mayasaftari@atmaluhur.ac.id
}

\begin{abstract}
Abstrak
Penelitian ini menghasilkan prototipe bahan ajar pokok bahasan jumlah Riemann berdasarkan teori APOS. Lembar aktivitas mahasiswa (LAM) berdasarkan teori APOS didesain untuk membantu mahasiswa memahami materi integral pokok bahasan jumlah Riemann. Proses desain bahan ajar dibagi menjadi dua tahapan yaitu preliminary study dan formative evaluation. Pada tahap preliminary study, peneliti melakukan persiapan serta pendesainan bahan ajar yang berupa lembar aktivitas mahasiswa pokok bahasan Jumlah Riemann berdasarkan teori APOS (Aksi, Proses, Objek, dan Skema). Tahap formative evaluation, peneliti melakukan evaluasi dan revisi terhadap hasil desain bahan ajar. Hasil evaluasi yang berupa komentar dan saran-saran dijadikan bahan untuk melakukan revisi pada produk yang telah dihasilkan yaitu prototipe pertama, kedua dan ketiga. Dari ketiga tahapan ini, prototipe pertama yang sudah didesain peneliti dilakukan revisi berdasarkan hasil komentar validator yaitu expert review dan beberapa mahasiswa. Prototipe kedua di revisi berdasarkan komentar beberapa kelompok mahasiswa dalam small grup. Prototipe ketiga merupakan hasil desain terakhir yang akan digunakan untuk uji lapangan pada tahap field test. Uji coba yang dilakukan menunjukkan bahwa tujuan menghasilkan desain produk yang memiliki efek potensial (keterpakaian) dalam proses pembelajaran matematika sudah tercapai.
\end{abstract}

Kata kunci: APOS, Integral, LAM, Riemann, Teori.

\begin{abstract}
This study produced a prototype of Riemann's number of teaching materials based on APOS theory. The student activity sheet (LAM) based on APOS theory was designed to help students understand the integral of the subject matter of Riemann quantities. The teaching materials design process was divided into two stages, namely preliminary study and formative evaluation. In the preliminary study stage, the researchers prepared and designed teaching materials in the form of student activity sheets for the subject of Riemann's Amount based on the APOS theory (Action, Process, Object, and Scheme). In the formative evaluation stage, researchers evaluated and revised the results of the design of teaching materials. The evaluation results in the form of comments and suggestions were used to revise the products produced, namely the first, second, and third prototypes. From these three stages, the first prototype that the researcher designed was revised based on the comments from the validator, namely expert review and several students. The second prototype was revised based on comments from several groups of students in small groups. The third prototype was the final design result used for field testing at the field test stage. The trials conducted showed that the goal of producing a product design that had a potential effect (usability) in the mathematics learning process had been achieved.
\end{abstract}

Keywords: APOS, Integral, LAM, Riemann, Theory.

Received: April 9, 2020/ Accepted: Juni 26, 2021/ Published Online: Juli 29, 2021 


\section{PENDAHULUAN}

Matematika merupakan bidang ilmu yang dapat diaplikasikan di berbagai bidang ilmu lainnya. Oleh karenanya di setiap perguruan tinggi selalu memasukkan matakuliah matematika pada kurikulumnya. Salah satu matakuliah matematika yang sering dimasukkan adalah kalkulus. Kalkulus merupakan matakuliah penting yang berisi konsep-konsep dasar matematika yang dapat digunakan untuk memecahkan permasalahan di berbagai bidang. Kalkulus merupakan mata kuliah yang sulit untuk dipahami, hal ini senada dengan pernyataan dalam penelitian Monariska (2019), yang mengemukakan bahwa mahasiswa mengalami kesulitan untuk memahami matakuliah kalkulus dan diperlukan pemahaman yang sangat mendalam. (Monariska, 2019).

Salah satu materi kuliah dalam matakuliah kalkulus adalah integral (anti turunan). Memahami integral juga tidak mudah, artinya pemahaman konsepnya juga harus lebih mendalam dan diperlukan waktu yang tidak sebentar. Kesulitan mahasiswa memahami konsep integral juga di jelaskan oleh Ramdani (2012) bahwa penyajian gambar grafik yang sesuai dan pemahaman simbolik yang sangat rendah. (Ramdani, 2012).

Menghitung volume benda putar, tidak bisa hanya menggunakan rumus volume saja kemudian diperoleh hasilnya. Fungsi yang menjadi batas daerah perlu disketsakan kemudian dari daerah yang terbentuk diputar pada sumbu putar tertentu sehingga hasil putarnya membentuk suatu bangun ruang tertentu yang mungkin saja bentuknya tidak beraturan. Selain itu, konsep integral tentu sendiri berasal dari jumlah Riemann yang cukup abstrak bagi kebanyakan mahasiswa. Hal inilah, yang membuat banyak mahasiswa kesulitan karena selain proses visualisasi yang tidak mudah digabungkan dengan konsep jumlah Riemann yang cukup rumit. (Romadiastri, 2016).

Dubinsky mengemukakan bahwa suatu pendekatan pembelajaran matematika di tingkat mahasiswa, yang menerapkan penggunaan komputer, diskusi dalam grup kecil, dan memperhatikan konstruksi mental yang dilakukan pembelajar dalam memahami konsep matematika atau dikenal dengan teori APOS. Konstruksi atau rekonstruksi tersebut dilakukan melalui aktivitas berupa aksi (action), proses (process), objek (object) yang diorganisasikan dalam bentuk skema (schema) yang disingkat APOS untuk mencari solusi dari suatu permasalahan.(Dubinsky \& Mcdonald, 2005). Teori APOS dapat digunakan untuk menggambarkan kemampuan peserta didik di tingkat bawah sampai atas dalam mempelajari konsep-konsep matematika. ( Rosali, Talib, \& Asdar, 2019). 
Pembelajaran berdasarkan teori APOS memungkinkan mahasiswa dapat secara aktif menemukan ide-ide matematika melalui berbagai fakta dalam proses pembelajaran yang didukung oleh bahan ajar yang dirancang berdasarkan tahapan konstruksi mental dari teori APOS. (Anwar \& Abdillah, 2016).

Penerapan teori APOS dalam pembelajaran matematika diperlukan perangkat pembelajaran yang efektif dan valid sehingga memungkinkan siswa dapat belajar secara giat dan dapat bekerjasama dengan teman sesuai dengan tahapan falsafah teori APOS. Hal ini tergambar dari beberapa penelitian yang sudah dilakukan peneliti sebelumnya. Penelitian terdahulu yang dilakukan oleh Wartini $\underline{(2011)}$ yaitu pengembangan modul berbasis teori APOS. Penelitian Nurlaelah $\underline{(2015)}$ juga menjelaskan bahwa pengembangan perangkat ajar diperlukan untuk meningkatkan kemampuan berpikir mahasiswa, kemampuan pemecahan masalah dan kemampuan berkomunikasi (Nurlaelah, 2015).

Hasil penelitian yang telah dilakukan menggambarkan bahwa adanya peningkatan kualitas pembelajaran mahasiswa, hal ini terbantu dengan adanya perangkat pembelajaran yang dibuat peneliti berdasarkan dengan teori APOS. Berdasarkan penelitian terdahulu dan kesulitan mahasiswa memahami konsep integral, maka peneliti tertarik untuk mengembangkan perangkat pembelajaran dalam bentuk bahan ajar berdasarkan teori APOS dengan materi jumlah Riemann. Pengembangan perangkat pembelajaran dalam bentuk lembar aktivitas mahasiswa (LAM) ini telah melalui beberapa tahapan dalam pengembangan dengan metode development study. (Saftari, Darmawijoyo, \& Hartono, 2020). Dalam setiap tahapannya, lembar aktivitas berupa prototipe selalu mengalami revisi karena di dalam metode pengembangannya, komentar dan saran-saran dari para ahli dan pembelajar (mahasiswa) digunakan dan di evaluasi untuk memperbaiki prototipe. Prototipe ini juga harus disesuaikan dengan falsafah dalam teori APOS tersebut.

\section{METODE}

Metode penelitian ini adalah penelitian design research tipe development study (studi pengembangan. (Akker, 1999). Pengembangan bahan ajar dibagi menjadi dua tahapan yaitu preliminary study dan tahap formative evaluation. Pada tahap preliminary study, peneliti melakukan persiapan serta pendesainan bahan ajar yang berupa lembar aktivitas mahasiswa pokok bahasan Jumlah Riemann berdasarkan teori APOS. Pada tahap evaluasi ini, peneliti menggunakan desain formative evaluation yang dikembangkan oleh Tessmer (Amalia \& Mulyono, 2020) seperti pada Gambar 1. 


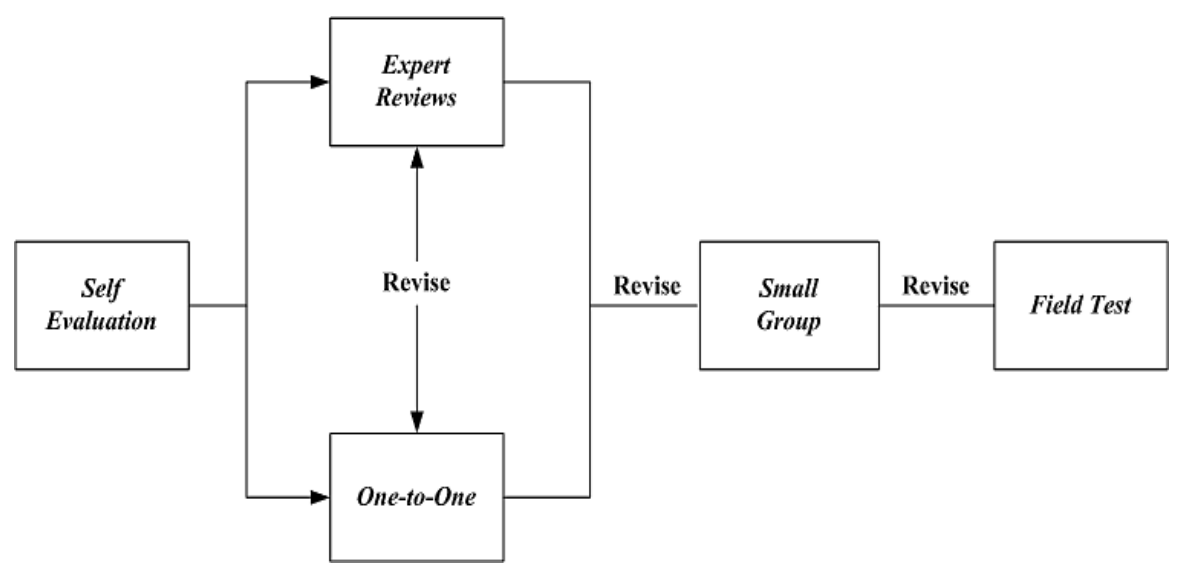

Gambar 1. Alur desain Formative Research

Pada tahap preliminary study, peneliti melakukan persiapan serta pendesainan bahan ajar yang berupa lembar aktivitas mahasiswa pokok bahasan Jumlah Riemann berdasarkan teori APOS (Aksi, Proses, Objek, dan Skema). Tahap formative evaluation, peneliti melakukan evaluasi dan revisi terhadap hasil desain bahan ajar. Hasil evaluasi yang berupa komentar dan saran-saran dijadikan bahan untuk melakukan revisi pada produk yang telah dihasilkan.

Penilaian dari validator berupa komentar/saran digunakan peneliti sebagai bahan acuan untuk memperbaiki prototipe. Validator untuk bahan ajar ini merupakan ahli dibidangnya sesuai dengan bahan ajar yang dikembangkan. Pada saat yang sama dengan tahap expert review bahan ajar juga diujicobakan pada beberapa orang mahasiswa yang bukan subyek penelitian memberikan komentar/saran dalam merevisi bahan ajar yang dibuat peneliti. Uji coba pada tahap one-to-one ini ditujukan untuk mengidentifikasi kesalahan dan hambatan atau kesulitan mahasiswa dalam mengerjakan LAM.

Hasil komentar/saran dari pakar (validator) dan hasil uji coba serta komentar/saran mahasiswa dijadikan sebagai bahan untuk merevisi serta memperbaiki desain prototipe pertama. Komentar beberapa kelompok mahasiswa dalam small grup. Prototipe ketiga merupakan hasil desain terakhir yang akan digunakan untuk uji lapangan pada tahap field test. Uji coba ini dilakukan untuk mengetahui apakah tujuan sesuai dengan apa yang diharapkan atau tidak yaitu menghasilkan desain produk yang memiliki efek potensial (keterpakaian) dalam proses pembelajaran. Forrmat evaluasi yang diberikan pada validator terlihat pada Tabel 1. 
Tabel 1. Format Evaluasi Validator

\begin{tabular}{|c|c|c|}
\hline No & Jenis Validasi & Aspek yang di nilai \\
\hline \multirow[t]{3}{*}{1} & Konten & a. Kesesuaian dengan Standar Kompetensi \\
\hline & & b. Kesesuaian dengan Kompetensi Dasar \\
\hline & & c. Kesesuaian dengan Tujuan Pembelajaran \\
\hline & Konstruk & $\begin{array}{l}\text { a. Sesuai dengan langkah teori APOS, yaitu: } \\
\text { 1) Ada langkah-langkah dalam kegiatan yang dapat } \\
\text { menimbulkan aksi bagi mahasiswa. }\end{array}$ \\
\hline & & $\begin{array}{l}\text { 2) Ada kegiatan yang dapat membuat } \\
\text { mahamahasiswa mengalami proses. }\end{array}$ \\
\hline & & $\begin{array}{l}\text { 3) Ada kegiatan yang dapat membangun struktur } \\
\text { pemahaman tentang konsep jumlah Riemann } \\
\text { yang merupakan kaitan aksi, proses dan objek } \\
\text { (skema) dalam pikiran mahamahasiswa. }\end{array}$ \\
\hline & & $\begin{array}{l}\text { b. Ada latihan untuk mengkokohkan konsep jumlah } \\
\text { Riemann yang telah dikonstruksi dan menerapkan } \\
\text { konsep jumlah Riemann yang telah dipelajari. }\end{array}$ \\
\hline
\end{tabular}

\begin{tabular}{|c|c|}
\hline \multirow[t]{4}{*}{ 3. Bahasa } & $\begin{array}{l}\text { a. Kesesuaian dengan Ejaan Yang Disempurnakan } \\
\text { (EYD) }\end{array}$ \\
\hline & b. Kejelasan petunjuk dan arahan \\
\hline & c. Kalimat mudah dimengerti \\
\hline & $\begin{array}{l}\text { d. Rumusan kalimat tidak menimbulkan penafsiran } \\
\text { ganda. }\end{array}$ \\
\hline
\end{tabular}

\section{HASIL PENELITIAN}

Tahap pendesainan bahan ajar melalui beberapa tahapan persiapan dan tahap pendesainan. Tahap pertama, desain bahan ajar dibuat peneliti dengan mengikuti tahap pengembangan development study. Penelitian ini diawali dengan melakukan diskusi dan wawancara informal dengan dosen pengampu matakuliah. Wawancara ini dilakukan dengan tujuan untuk melakukan analisis latar belakang kemampuan matematika mahasiswa. Setelah mendapatkan informasi tentang kemampuan matematika mahasiswa yang akan dijadikan subyek penelitian, kegiatan selanjutnya adalah analisis kurikulum. Analisis kurikulum yang dihasilkan disesuaikan dengan kompetensi dasar, indikator pembelajaran, dan tujuan pembelajaran. Dalam prosesnya, peneliti dibantu teman sejawat. Hasil analisis terlihat pada Tabel 2. 
Tabel 2. Analisis Kurikulum

\begin{tabular}{|c|c|c|}
\hline No & & Analisis Kurikulum \\
\hline 1. & Kompetensi Dasar & $\begin{array}{l}\text { Menggunakan jumlah Riemann untuk menghitung luas } \\
\text { daerah }\end{array}$ \\
\hline \multirow[t]{3}{*}{2.} & \multirow[t]{3}{*}{ Indikator Pembelajaran } & $\begin{array}{l}\text { 1. Menggambarkan suatu daerah yang dibatasi oleh } \\
\text { beberapa kurva. }\end{array}$ \\
\hline & & $\begin{array}{l}\text { 2. Menentukan luas daerah dengan menggunakan } \\
\text { jumlah Riemann. }\end{array}$ \\
\hline & & $\begin{array}{l}\text { 3. Merumuskan jumlah Riemann untuk luas daerah dan } \\
\text { menghitungnya. }\end{array}$ \\
\hline \multirow[t]{2}{*}{3.} & \multirow[t]{2}{*}{ Tujuan Pembelajaran } & $\begin{array}{l}\text { 1. Mahasiswa diharapkan dapat menggambarkan } \\
\text { daerah yang di batasi oleh kurva menseketsa grafik } \\
\text { fungsi }\end{array}$ \\
\hline & & $\begin{array}{l}\text { 2. Mahasiswa diharapkan dapat menentukan luas } \\
\text { daerah yang dibatasi kurva. }\end{array}$ \\
\hline
\end{tabular}

Pada tahap pendesainan, peneliti mendesain LAM jumlah Riemann berdasarkan teori APOS. LAM ini di desain dengan menggunakan bantuan komputer yaitu software Microsoft Excel. LAM terdiri dari 4 aktivitas yang dilengkapi dengan soal latihan. Pada tahap formative evaluation, peneliti mengevaluasi kembali desain lembar aktivitasnya yang dilihat dari segi isi, konsep yang sesuai dengan materinya atau dalam hal ini konstruk, maupun penggunaan bahasa. Peneliti mengevaluasi sendiri apakah desain yang telah dibuat sesuai dengan teori belajar APOS. Expert Review, Pada tahap ini hasil desain prototipe pertama diberikan kepada pakar untuk divalidasi. Prototipe pertama yang telah didesain berdasarkan teori APOS diberikan kepada pakar untuk divalidasi sesuai dengan isi, konsep yang sesuai dengan materinya atau dalam hal ini konstruk dan penggunaan bahasa. Hasil validasi dari para pakar terhadap prototipe pertama dapat dilihat pada Tabel 3.

Tabel 3. Hasil Validasi Pada Tahap Expert Review

\begin{tabular}{|c|c|c|}
\hline No & Reviewer & Saran dan Komentar \\
\hline & Reviewer 1 & $\begin{array}{l}\text { - Aktivitas untuk konstruksi mental objek belum } \\
\text { tampak } \\
\text { - Aktivitas untuk konstruksi mental APOS lainnya } \\
\text { sudah bagus. } \\
\text { - Untuk soal no. } 1 \text { apakah dapat menghitung luas } \\
\text { daerah di bawah kurva kalau persamaan kurva } \\
\text { tidak diketahui. }\end{array}$ \\
\hline & Reviewer 2 & $\begin{array}{l}\text { - Kalimat yang menunjuk nama Gambar hanya } \\
\text { 1, yaitu Gambar 1. (Halaman 9). Selainnya }\end{array}$ \\
\hline
\end{tabular}




\begin{tabular}{ll}
\hline No Reviewer & \multicolumn{1}{c}{ Saran dan Komentar } \\
\hline & tidak jelas gambar yang dimaksud oleh \\
& kalimat. \\
- & Berikan kalimat yang menunjuk masing- \\
& masing gambar, supaya mahasiswa jelas \\
& memahami gambar yang dimaksud oleh soal \\
& atau oleh penjelasan. Lebih dirinci dan \\
& dioperasionalkan pada aktivitas APOS, apa boleh \\
& tidak runtun, misal proses, aksi lalu objek. Pahami \\
& Teori tentang APOS. \\
- & Pada Aktivitas 2 dan Aktivitas 3, tidak \\
& dimasukkan rumus jumlah luas empat persegi \\
& panjang. \\
& Sebaiknya pada Aktivitas 2 dan Aktivitas 3, \\
& dimasukkan rumus jumlah luas empat persegi \\
panjang, untuk melatih daya ingat mahasiswa.
\end{tabular}

Prototipe pertama diberikan kepada pakar sebagai proses validasi secara konten, konstruk dan bahasa. Tahap one-to-one, prototipe pertama diujicobakan kepada tiga orang mahasiswa yang bukan merupakan subjek penelitian. Pada kegiatan one-to-one, salah satu temuan yang diperoleh peneliti adalah dari hasil jawaban mahasiswa adalah sulit memahami perintah yang ada di aktivitas 3 dan 4. Selanjutnya, peneliti melakukan tanya jawab secara tertulis kepada mahasiswa tentang kendala dan kesulitan dalam pengerjaan lembar aktivitas. Komentar pada tahap one-to-one evaluation dapat dilihat dalam Tabel 4.

Tabel 4. Komentar Mahasiswa Pada Tahap One-to-one

\begin{tabular}{cll}
\hline Komentator & \multicolumn{1}{c}{ Komentar } \\
\hline MR & - & Aktivitas 2 langkah 19 dan aktivitas 4 terlalu \\
& membingungkan sehingga sulit dipahami. \\
& Terlalu banyak langkah-langkah sehingga sulit \\
& dikerjakan. \\
& - & Ada beberapa soal yang sulit dipecahkan. \\
\hline MT & - & Aktivitas 3 dan 4 terlalu banyak persegi \\
& panjang sehingga menggunakan waktu yang \\
& lama. \\
& - & Penjelasan tentang tahapan pada microsoft \\
& excel kurang mudah dipahami dan kurang \\
& penjelasan perintah dari microsoft excel. \\
& - & LAM ini tidak terlalu sulit untuk dipahami. \\
\hline IAN & - & LAM masih banyak kekurangan \\
& - & Lebih permudah lagi caranya \\
\hline
\end{tabular}


Komentar dan saran ini merupakan keterangan yang sangat penting yang digunakan untuk merevisi dan memperbaiki desain prototipe pertama. Dari komentar dan saran terlihat adanya kekurangan pada prototipe pertama sehingga desain direvisi hanya pada kekurangan tersebut. Hasil revisi tersebut menghasilkan prototipe kedua yang akan diujicobakan kepada 3 kelompok mahasiswa yang bukan merupakan subjek penelitian. Hal ini dilakukan guna melihat apakah desain prototipe praktis (mudah) untuk digunakan. Kegiatan small group dilakukan di laboratorium karena memanfaatkan komputer dalam mengerjakan lembar aktivitas mahasiswa. Kegiatan ini terlihat pada Gambar 2.

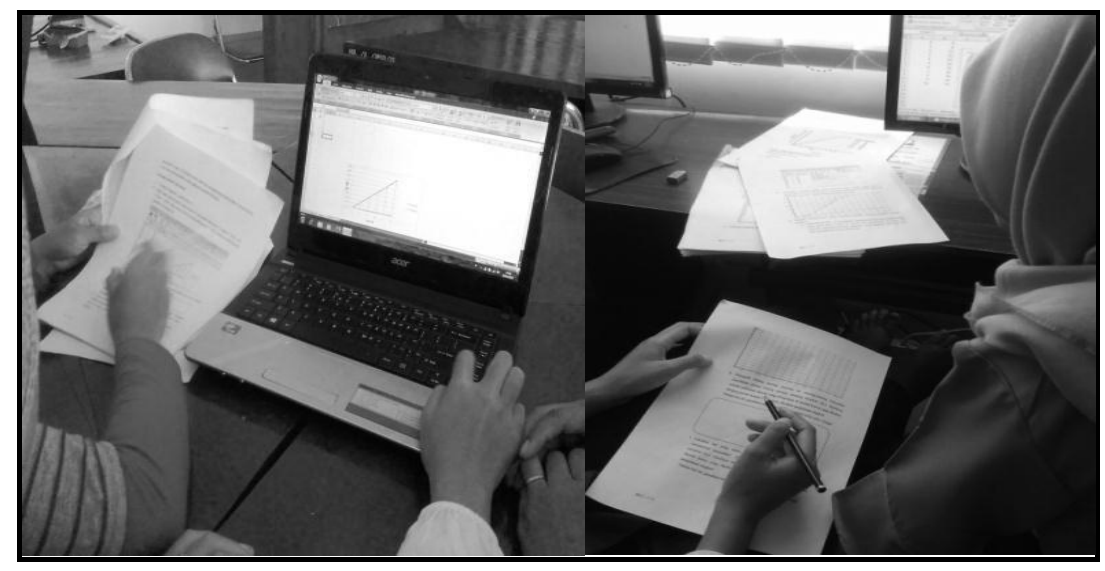

Gambar 2. Kegiatan Small Group di Laboratorium

Dalam ujicoba ini, masing-masing kelompok diminta untuk mengerjakan lembar aktivitas dan diminta juga untuk memberikan komentar masing-masing kelompok. Komentar dan saran yang diberikan oleh kelompok ini, merupakan informasi untuk memperbaiki desain protipe kedua. Perbaikan terhadap desain produk pada tahap ini tidak begitu banyak, karena dibatasi hanya pada kepraktisan prototipe. Hasil revisi ini menghasilkan desain prototipe ketiga yang digunakan pada tahap uji lapangan. Uji lapangan (field test) merupakan tahapan terakhir dalam proses penelitian.

Desain prototipe ketiga diujicobakan pada mahasiswa yang berjumlah 26 orang dan dibagi menjadi 6 kelompok dengan kemampuan matematika yang heterogen. Proses pembelajaran berlangsung di ruang kelas dan laboratorium komputer. Peneliti melakukan analisis kemampuan kognitif mahasiswa yang menjadi subyek penelitian, sehingga grup subyek penelitian yang terbentuk beragam (heterogen) dan hasil uji lapangan juga beragam. Komentar kelompok pada tahap Small Group dapat dilihat pada Tabel 5. 
Tabel 5. Komentar Mahasiswa Pada Tahap Small Group

\begin{tabular}{|c|c|}
\hline Komentator & Komentar \\
\hline Kelompok 1 & $\begin{array}{l}\text { - LAM ini sangat membantu memahami materi integral } \\
\text { pokok bahasan jumlah Riemann } \\
\text { - Pada aktivitas 3, langkah } 1 \text { sebaiknya diberi langkah- } \\
\text { langkah untuk menjawab soal pada tabel } 1 \text {. } \\
\text { - Di beri penjelasan singkat mengenai penggunaan } \\
\text { software Microsoft Excel. }\end{array}$ \\
\hline Kelompok 2 & $\begin{array}{l}\text { - Pada aktivitas } 3 \text { pada tabel 1, langkah } 1 \text { sebaiknya jumlah } \\
\text { persegi panjangnya tidak terlalu banyak karena } \\
\text { membutuhkan waktu yang lama untuk mengerjakannya } \\
\text { - Kalimat perintah pada soal agar diperjelas sehingga } \\
\text { mudah untuk dipahami. } \\
\text { - } \\
\text { Aktivitas } 3 \text { dan } 4 \text { sebaiknya berurutan langkah kerjanya } \\
\text { disesuaikan dengan aktivitas } 2 \text {. }\end{array}$ \\
\hline Kelompok 3 & $\begin{array}{l}\text { - Pengaplikasian LAM dapat mempermudah mahasiswa } \\
\text { memahami materi integral pokok bahasan jumlah } \\
\text { Riemann } \\
\text { - Di beri penjelasan singkat mengenai penggunaan } \\
\text { software Microsoft Excel, terutama dalam } \\
\text { menggambarkan grafik. }\end{array}$ \\
\hline
\end{tabular}

\section{PEMBAHASAN}

Lembar aktivitas mahasiswa (LAM) merupakan contoh bahan ajar yang memungkinkan mahasiswa belajar mandiri. Lembar aktivitas mahasiswa ini didesain oleh peneliti guna membantu mahasiswa memahami konsep Jumlah Riemann pada materi integral (anti turunan). Lembar kegiatan mahasiswa juga pernah dikembangkan oleh Prihaswati, Purnomo, Sukestiyarno (2018) dengan materi anti turunan dengan pendekatan konstruktivisme. Lembar kegiatan ini juga dikembangkan untuk membantu mahasiswa memahami konsep matematika.(Prihaswati, Purnomo, \& Sukestiyarno, 2018).

Persiapan dan pendesainan bertujuan untuk merancang lembar aktivitas mahasiswa (LAM) dengan pendekatan teori aksi, proses, objek, dan skema (APOS). Pendekatan teori APOS dipilih karena dapat digunakan untuk membandingkan tingkat penguasaan dan pemahaman konsep masing-masing individu. (Syafri, 2016). Pemahaman akan berbeda-beda antara individu satu dengan individu lainnya, tergantung tingkat konstruksi dari individunya. (Natali, Sujatmiko, \& Chrisnawati, 2017).

Persiapan pendesainan dilakukan kerjasama dan pengaturan jadwal dengan perguruan tinggi tempat peneliti melakukan penelitian. Kegiatan ini tidak mengalami kesulitan yang sangat berarti karena pihak perguruan tinggi memberikan kesempatan yang seluas-luasnya kepada peneliti. Kegiatan pendesainan dilakukan dengan menganalisis kurikulum, standar 
kompetensi dan kemampuan dasar yang harus dicapai serta tujuan pembelajaran. Proses dilanjutkan dengan mendesain lembar aktivitas jumlah Riemann yang didesain berdasarkan dekomposisi genetik yang sesuai dengan dasar teori aksi, proses, objek, dan skema (APOS). Dekomposisi genetik merupakan kumpulan aktivitas mental yang dilakukan individu secara sistematis untuk menggambarkan bagaimana konsep matematika dapat dikembangkan dalam pikiranya. (Widada \& Herawaty, 2017). Berdasarkan analisis dekomposisi genetik inilah lembar aktivitas mahasiswa didesain dengan 4 aktivitas yang didalamnya terdapat kegiatan yang membimbing mahasiswa menentukan nilai fungsi, mengamati bangun ruang, dan menentukan hasil pengamatan.

Dalam pendesaian LAM ini, semua tahap evaluasi desain dari expert review, one-to-one, small group dilakukan untuk perbaikan dan revisi dari hasil pendesainan awal oleh peneliti. Tahapan ini produk yang dihasilkan adalah prototipe pertama, kedua, dan ketiga. (Lestarianingsih, Darmawijoyo, \& Hartono, 2015).

Desain lembar aktivitas yang diberikan kepada para validator (expert review) sudah dinyatakan memenuhi setiap unsur konten, konstruk dan bahasa berdasarkan teori APOS. Tiga orang mahasiswa yang memiliki kemampuan yang berbeda dalam tahap one-to-one, juga tidak mengalami kesulitan yang signifikan dalam menyelesaikan lembar aktivitas. Dengan demikian desain awal lembar aktivitas mahasiswa tidak banyak mengalami perubahan. Perbaikan dan revisi lembar aktivitas mahasiswa (LAM) pada kegiatan small group juga tidak mengalami perubahan yang signifikan hanya saja ada beberapa kalimat yang perlu perbaikan karena kurang bisa dipahami dan dimengerti oleh mahasiswa. Perbaikan lembar aktivitas pada tahap inilah yang nanti akan digunakan untuk kegiatan field test. Desain lembar aktivitas pada kegiatan field test, sudah dinyatakan valid dan praktis untuk digunakan.

\section{SIMPULAN}

Berdasarkan hasil penelitian yang diperoleh, maka dapat disimpulkan bahwa desain bahan ajar lembar aktivitas mahasiswa (LAM) berdasarkan teori APOS melalui dua tahapan yaitu preliminary study dan tahap formative evaluation. Tahap preliminary study melalui tahap persiapan dan pendesainan yang dilakukan sendiri oleh peneliti. Pendesaian bahan ajar berdasarkan falsafah teori aksi, proses, objek dan, skema (APOS). Tahap ini menghasilkan prototipe pertama. Tahap formative evaluation melalui tahap expert review (validator), one-toone, small group, dan field test. Tahap expert review (validator) dan one-to-one dilakukan dengan waktu yang bersamaan. Tahap ini menghasilkan prototipe kedua berdasarkan hasil 
revisi yang didasarkan pada komentar dan saran dari validator dan mahasiswa. Tahap small group dilakukan oleh tiga kelompok saja dimana masing-masing kelompok mencoba mengerjakan lembar aktivitas mahasiswa (LAM). Hal ini dilakukan guna melihat apakah desain prototipe praktis (mudah) untuk digunakan pada tahap ini menghasilkan prototipe ketiga. Prototipe ketiga merupakan hasil desain terakhir yang akan digunakan untuk uji lapangan pada tahap field test. Uji coba yang dilakukan menunjukkan bahwa tujuan menghasilkan desain produk yang memiliki efek potensial (keterpakaian) dalam proses pembelajaran matematika sudah tercapai.

\section{REFERENSI}

Amalia, W., Mulyono, E. E. N. (2020). Development of Pisa-Like Mathematical Problems on The Change and Relationship Content to Measure the Mathematical Solution Ability of Middle School Students Development of Pisa-Like Mathematical Problems on The Change and Relationship Content to Measure t. International Journal of Advanced Science and Technology, 29(6), 4841-4849.

Anwar, Y. S., \& Abdillah, A. (2016). Penerapan Teori Apos (Action, Process, Object, Schema) Untuk Meningkatkan Pemahaman Konsep Program Linier Bagi Mahasiswa Program Studi Pendidikan Matematika Tahun Akademik 2015/2016. Paedagoria | FKIP UMMat, 7(2), 53. https://doi.org/10.31764/paedagoria.v7i2.30

Dubinsky, E., \& Mcdonald, M. A. (2005). APOS: A Constructivist Theory of Learning in Undergraduate Mathematics Education Research. In The Teaching and Learning of Mathematics at University Level (pp. 275-282). Kluwer Academic Publishers. https://doi.org/10.1007/0-306-47231-7_25

Lestarianingsih, Y., Darmawijoyo, \& Hartono, Y. (2015). Pengembangan Lembar Aktivitas Mahasiswa Topik. Jurnal Pendidikan Matematika Dan Sains, 3(1), 10-22.

Monariska, E.-. (2019). Analisis kesulitan belajar mahasiswa pada materi integral. Jurnal Analisa, 5(1), 9-19. https://doi.org/10.15575/ja.v5i1.4181

Natali, S. S., Sujatmiko, P., \& Chrisnawati, H. E. (2017). Analisis Tingkat Pemahaman Siswa Berdasarkan Teori Apos Pada Materi Persamaan Kuadrat Ditinjau Dari Minat Belajar Siswa Kelas X SMA Negeri 2 Surakarta Tahun Ajaran 2015/2016. Pendidikan Matematika Dan Matematika (JPMM), 1(5), 104-117.

Nurlaelah, E. (2015). Pengembangan Bahan Ajar Struktur Aljabar Yang Berbasis Program Komputer Dan Tugas Resitasi Untuk Meningkatkan Kreativitas Dan Daya Matematik Mahasiswa. Jurnal Pengajaran Matematika Dan Ilmu Pengetahuan Alam, 14(2). https://doi.org/10.18269/jpmipa.v14i2.297

Prihaswati, M., Purnomo, E, Sukestiyarno, S, M. M. (2018). Lesson Study: Pengembangan Lembar Kerja Mahasiswa pada Pembelajaran Matematika Dasar di Perguruan Tinggi. Jurnal Karya Pendidikan Matematika, 5(2), 101-106. 
Ramdani, Y. (2012). Pengembangan Instrumen dan Bahan Ajar untuk Meningkatkan Kemampuan Komunikasi, Penalaran, dan Koneksi Matematis dalam Konsep Integral. Jurnal Penelitian Pendidikan, 13(1), 44-52.

Romadiastri, Y. (2016). Penerapan Pembelajaran Kontekstual Pada Kalkulus 2 Bahasan Volum Benda Putar. Phenomenon: Jurnal Pendidikan MIPA, 1(1), 131-143. https://doi.org/10.21580/phen.2013.3.1.179

Rosali, D., Talib, \& Asdar. (2019). Deskripsi Kemampuan Pemahaman Konsep Turunan Berdasarkan Teori Apos Pada Siswa Kelas XII MIA-1 SMAN Makassar. 3(1), 49-57.

Saftari, M., Darmawijoyo, \& Hartono, Y. (2020). Development of student activities sheet based on apos theory to understand the concept of Riemann sum. Math Didactic: Jurnal Pendidikan Matematika, 6(1), 110-123. https://doi.org/10.33654/math.v6i1.914

Syafri, F. S. (2016). Pemahaman matematika dalam kajian teori apos (action, process, object, and schema ). At-Ta'lim, 15(2).

Akker,V.D. J. (1999). Principles and Methods of Development Research. In Design Approaches and Tools in Education and Training (pp. 1-14). Springer, Dordrect. https://doi.org/10.1007/978-94-011-4255-7_1

Wartini. (2011). Pengembangan Modul Kalkulus II Pokok Bahasan Persamaan Diferensial Biasa Berbasis Teori APOS. Tesis Program Pascasarjana Universitas Sriwijaya.

Widada, W., \& Herawaty, D. (2017). Dekomposisi Genetik tentang Hambatan Mahasiswa dalam Menerapkan Sifat-sifat Turunan. Jurnal Didaktik Matematika, 4(2), 136-151. https://doi.org/10.24815/jdm.v4i2.9216 